\title{
Solar energy policy to boost Brazilian power sector
}

\author{
Juliana Pacheco Barbosa
}

CENSE - Center for Environmental and Sustainability Research, Faculdade de

Ciências e Tecnologia, Universidade Nova de Lisboa, Caparica, Portugal and

Instituto Universitário de Lisboa (ISCTE-IUL), Lisbon, Portugal

Joisa Dutra Saraiva

CERI-Centro de Estudos em Regulação e Infraestrutura,

Fundação Getúlio Vargas, Rio de Janeiro, Brazil, and

Julia Seixas
CENSE - Center for Environmental and Sustainability Research, Faculdade de Ciências e Tecnologia, Universidade Nova de Lisboa, Caparica, Portugal

\begin{abstract}
Purpose - The purpose of this paper is to highlight the opportunity for the energy policy in Brazil to tackle the very high cost-effectiveness potencial of solar energy to the power system. Three mechanisms to achieve ambitious reductions in the greenhouse gas emissions from the power sector by 2030 and 2040 are assessed wherein treated as solar targets under ambitious reductions in the greenhouse gas emissions from the power sector. Then, three mechanisms to achieve these selected solar targets are suggested.
\end{abstract}

Design/methodology/approach - This paper reviews current and future incentive mechanisms to promote solar energy. An integrated energy system optimization model shows the most cost-efficient deployment level. Incentive mechanisms can promote renewable sources, aiming to tackle climate change and ensuring energy security, while taking advantage of endogenous energy resources potential. Based on a literature review, as well as on the specific characteristics of the Brazilian power system, under restrictions for the expansion of hydroelectricity and ambitious limitation in the emissions of greenhouse gases from the power sector.

Findings - The potential unexploited of solar energy is huge but it needs the appropriate incentive mechanism to be deployed. These mechanisms would be more effective if they have a specific technological and temporal focus. The solar energy deployment in large scale is important to the mitigation of climate change.

Originality/value - The value of the research is twofold: estimations of the cost-effective potential of solar technologies, generated from an integrated optimization energy model, fully calibrated for the Brazilian power

(C) Juliana Pacheco Barbosa, Joisa Dutra Saraiva and Julia Seixas. Published by Emerald Publishing Limited. This article is published under the Creative Commons Attribution (CC BY 4.0) licence. Anyone may reproduce, distribute, translate and create derivative works of this article (for both commercial and non-commercial purposes), subject to full attribution to the original publication and authors. The full terms of this licence may be seen at $\mathrm{http} / /$ creativecommons.org/licences/by/4.0/ legalcode

The authors wish to thank Climate-Kic for the opportunity of professional mobility, under Pioners into Practice Programe; Finally, I acknowledge the anonymous reviewers for their valuable comments and suggestions which have improved meaningfully the manuscript.

Funding: This research was supported by Conselho Nacional de Desenvolvimento Cientifico e Tecnologico - CNPq, by a doctoral scholarship for Juliana Pacheco Barbosa in the Science Without Borders Program, process number 207070/2014-8.

Solar energy policy

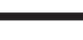

Received 12 July 2019 Revised 16 July 2019 10 December 2019

21 January 2020

4 March 2020

Accepted 11 March 2020

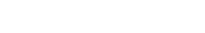


IJCCSM 12,3

system, while tacking the increasing electricity demand, the expected reduction of greenhouse gas emissions and the need to increase the access to clean and affordable energy, up to 2040; proposals of three mechanisms to deploy centralized PV, distributed PV and solar thermal power, taking the best experiences in several countries and the recent Brazilian cases.

Keywords Brazilian power auctions, Climate change mitigation, Renewable energy incentive mechanisms

Paper type Research paper

\section{Introduction}

The transition to a carbon-neutral economy has been considered a worldwide commitment, propelled by the Paris Agreement. Brazilian emissions targets or nationally determined contributions (NDC), committed to a 43\% reduction of greenhouse gas emissions by 2030 against a 2005 baseline (FEDERATIVE REPUBLIC OF BRAZIL, 2015). Energy systems are key to decarbonizing economies and various public policy decarbonization strategies acknowledge the growing demand for the intermittent availability of endogenous energy sources, and respective technological infrastructures. Despite this, a key umbrella policy worldwide aims at an increase in renewable sources for electricity generation. In the last years, investments supporting the increase of the renewable power capacity have been higher than investments in the fossil-based power capacity, at US\$297bn in 2016 (IEA, 2017a).

Even though the costs of renewable electricity have reduced significantly, considerable investment is required to make renewables play a relevant role in energy transition, due to the fact that both centralized wind and solar power are capital-intensive projects (IRENA, 2016). Considering the multiple social gains associated with renewable energy sources (e.g. public health, energy access, global warming limitation and job creation), public policies in many countries are dedicated to developing mechanisms and instruments to promote them (Kitson et al., 2011). Analyzing the Spanish case, compared with German, Danish and Chinese one, the research of Rialp-criado et al. (2019) concluded that to the development emerging industry related to the renewable energy is essential stable and long term public policy. Similarly, the "stop and go" behaviour of public policies acts as an institutional barrier for solar deployment. The majority of investments in global power generation in 2016 were undertaken within a regulatory framework capable of withstanding the revenue risks of variable wholesale market pricing (IEA, 2017a). Direct investment from the public sector represented just 3.8\% of total investments in renewable power generation in 2017, as estimated by IRENA (REN21, 2018). Therefore, the development of an appropriate regulatory environment is essential to shift private sector investment from non-renewable to renewable power sources, accounting for growing electricity demands (REN21, 2017).

Different policy instruments have different impacts on the adoption of renewables, due to the cost-effectiveness of the technologies when taking the energy system features as a whole. This paper claims that the effectiveness of different instruments to promote renewables must be assessed by approaching the energy system as a whole, to reflect the role of various energy technologies for different energy uses, namely, in terms of their efficiency and costs. This paper aims to provide a more comprehensive approach of public policy to solar energy deployment on a large scale.

The goal of this paper is to discuss the effectiveness of current policy instruments used in Brazil to promote renewable energy sources and solar, in particular, with a view to proposing future instruments to boost the high potential of solar power in the country. The Brazilian power sector is selected as the case study because it presents the following challenges: an expected significant increase in electricity demand, increasing number of 
protests at new hydropower plant for environmental reasons and the great success of the performance of some current policy instruments, such as auctions. It is argued there are conditions to greatly expand the share of solar in the Brazilian power sector, and this paper discusses proposals on policy instruments to reach that potential.

An integrated energy system optimization model (The Integrated Market allocation model [MARKAL]-Energy flow optimization model [EFOM] System [TIMES_BR_light] was used to identify cost-effective solar power deployment levels for 2030 and 2040, according to selected scenarios, regarding the greenhouse gas emissions reduction required by the Paris Agreement aims. These more cost-effective solar power development levels will here in this paper go by the name of targets, but they are the results of an optimization model instead of a technical-political process of a definition of goals for public policies.

Brazil's NDCs to fight climate change under the Paris Agreement estimate a reduction of $43 \%$ in total emissions, including land use and land-use change. After the Energy Research Company, in Portuguese Empresa de Pesquisa Energética (EPE, 2016a), the power sector emissions of greenhouse gases could increase from 26 million tons of $\mathrm{CO}_{2 \mathrm{eq}}$ in 2005 to 73 million tons of $\mathrm{CO}_{2 \mathrm{eq}}$ in 2030. This paper argues that solar energy could contribute in an efficient way to a more ambitious contribution from the Brazilian power sector to the mitigation of climate change with a reduction of $80 \%$ of emissions in 2030 compared with the before mentioned value, wherein the total expected emissions reduction is applied to the power sector. The most updated Brazilian emissions inventory reported to United Nations Framework Convention on Climate Change (UNFCCC) is 2015 and indicates that Brazilian emissions represented in 2015, $4.58 \%$ of world total emissions of greenhouse gas (UNFCCC, 2019).

This paper is structured as follows: section 1 provides the introduction, section 2 describes current solar energy incentives both worldwide and in Brazil, section 3 proposes future policy incentives to achieve solar targets derived from the TIMES_BR_light model and section 4 provides a conclusion.

\section{Solar power incentives}

Instruments to encourage the use of renewable energy sources in the electricity sector are multiple and diverse in terms of the application period, focus of incidence and reward schemes, and may include feed-in tariffs (FITs), auctions, quotas, direct subsidies, tax reductions and carbon taxes (Aquila et al., 2017). A growth of such instruments has been observed worldwide. The most widely adopted mechanism is the FIT, having been implemented in over 80 countries in 2016 (REN21, 2017). The International Energy Agency (IEA) estimated that $59 \%$ of photovoltaic (PV) installation took place under a FIT scheme in 2016 (IEA, 2017b). Auctions come in second place, also with significant growth, reaching about 35 countries. According to the Energy Research Company of Brazil (EPE, 2016b), there are five incentive mechanisms being used for solar sources: quotas, premium or FITs, subsidies, auctions and net metering; they may be applied singly or in combination.

\subsection{Solar energy incentive mechanisms worldwide}

To reflect the impact of the incentive mechanisms adopted globally, the top 10 countries regarding solar PV power generation were ranked and their growth observed in terms of electricity production between 2012 and 2016 and the relative importance of PV in the national power matrix in 2016. For these countries, the policy incentives adopted and the incentive focus were assessed. Table 1 presents the assessment of the top 10 countries, which represents $84 \%$ of the world solar PV electricity produced in 2016 . The top three producers are non-European countries and have experienced huge growth rates between 2012 and 2016. A diversity of incentive mechanisms adopted by the group can be observed. 
IJCCSM

12,3

352
Table 1.

PV deployment and incentive mechanism in selected countries

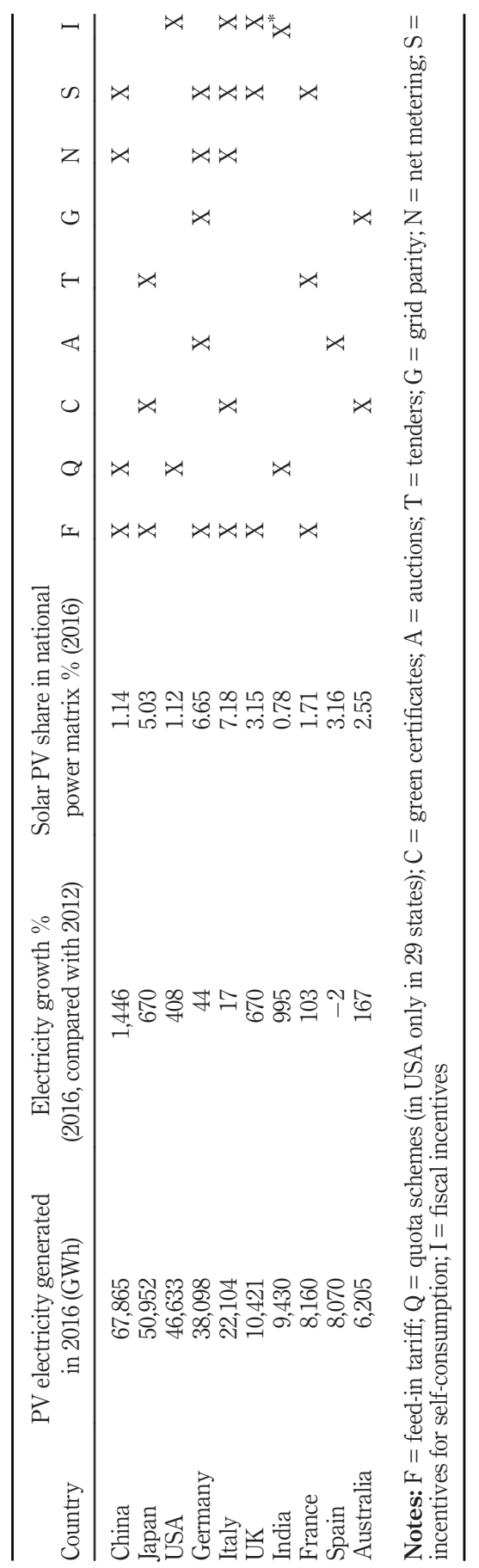


China is the leading country for the deployment of solar PV power, although its share in the electricity mix is very low, while Italy and Germany show the highest share, around $7 \%$. Some countries have opted to award support based on their market competition, justified by the observed cost reduction of solar technologies (IEA, 2018). The Chinese solar policy is a good example of the effectivity of a solar policy, after Ye et al. (2017) in 2008 the installed capacity was 140 MW. A first phase of policies in 2009 with Solar Roofs Program and Golden Sun Demonstration Program supported 3,423 MW. Sponsored tenders and a FIT policy followed these programmes. In 2016, with a 67,100 MW the problem was the related with spatial distribution of the installations and another type of policies with combination of quotas and FIT and the construction of ultrahigh transmission lines.

From Table 1, the majority of the selected countries make use of more than one incentive mechanism. The FIT is the most common mechanism, but self-consumption incentives are also present in many countries. These incentives have been adapted and revised, with changes in conditions and design. For instance, a certificate scheme called the Renewable Obligation Certificate (ROC) in place between 2002 and 2017 was discontinued in the UK after 31 March 2017, although some generators were able to participate in the scheme for a period of grace until September 2018 (Ofgem, 2018). In Italy, Green Certificates were an option between 2012 and 2017 and were then changed to an all-inclusive FIT. Japan decided to implement green certificates in 2017, and China is considering this alternative to ensure the financial health of the incentive mechanism (IEA-PVPS, 2018).

\subsection{Solar energy incentive mechanisms in Brazil}

Two types of incentives for solar energy at different scales will be discussed in this section, namely, solar auctions and net metering regulations. The first addresses utility-scale plants with a focus on grid supply. The second is related to rooftop technologies for the building sector, mainly but not exclusively for the residential sector.

2.2.1 Auctions in Brazil. To discuss solar energy auctions, auction mechanisms within Brazil must be assessed. Auctions for power generation contracts began in Brazil after the process of restructuring the electricity sector in 2004. They are part of a new regulatory framework (Dutra and Menezes, 2005), in which the following triple objective was required: efficient contracting mechanisms, security of supply and universal access.

The structure of the electricity market in the regulated environment is as follows:

- the distributors of electricity reveal the forecasted demand and communicate it to the Ministry of Mines and Energy (MME - Ministério de Minas e Energia);

- MME organize auctions for generation capacity; and

- distributors arrange contracts for the forecasted electricity demand with auction winners; winners are selected based on their ability to offer the lowest energy costs.

In the regulated contracting environment between 2004 and April 2018, 67 electric power auctions were carried out in Brazil, resulting in the agreement of 26,544 electricity contracts. Auctions took place through six different modes, namely, existing energy, new energy, structuring, backup energy, tuning and alternative sources. Table 2 explains the main features and presents selected results of the auctions occurring in Brazil in this period. It is important to note that the restructuring of the regulatory framework, of which the auctions are a fundamental part, was a response to the power shortage that the country experienced between 2001 and 2002, the so-called Apagão (blackout), where the electricity supply was unable to meet electricity demand due to insufficient investments in the generation and transmission systems.

Solar energy policy

353

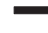


IJCCSM

12,3

354

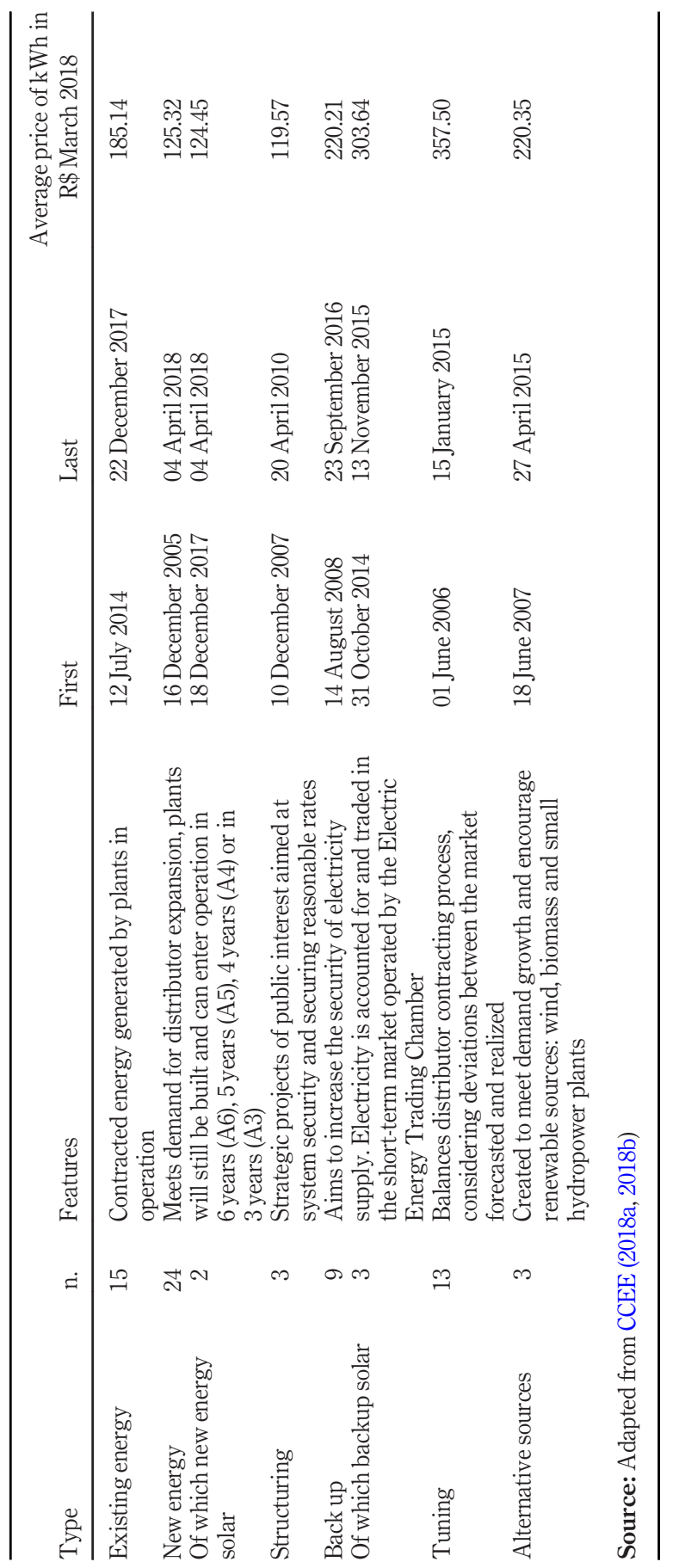

Table 2.

Characteristics and results of auctions occurred in Brazil in the period 2004-2018 
Figure 1 shows all the valid auction contracts by energy source, showing supply between 2014 and 2030; there is a noticeably higher contribution of fossil fuels in the early years, which declines in the mid-2020s, with a reduction in coal and the elimination of the oil-based electricity supply. The hydropower contracts both within and outside the Amazon region are of longer duration. Contributions from solar PV remain low.

Five auctions occurred in the lead-up to February 2019, with the potential deployment of utility-scale solar energy; these were divided into two phases, the first with three auctions in 2014 and 2015, and the second with two auctions in 2017 and 2018. Between these two periods, an uncontracted mechanism took place to avoid discouraging future solar energy investments. At that time, the previous contracted project faced a significant challenge, with estimated costs for imported equipment during the plant-planning phase at an exchange rate higher than that agreed during the initial purchase of equipment. The exchange rate risks were not well assessed in the initial phase, causing some of the planned plants to experience delays or in some cases not to be built at all. The response of the power regulator was to cancel the contracts for those plants which could not be built.

Table 3 presents a synthesis of the auctions for utility-scale solar energy occurring in Brazil up to June 2019. Each column represents an auction process; LER is the Portuguese acronym for Reserve Energy Auction and LEN for New Energy Auction. This difference between the categories of an auction is one of the signs of maturity of the source in the Brazilian electricity market; in the first phase, the solar energy was sold to the system as an

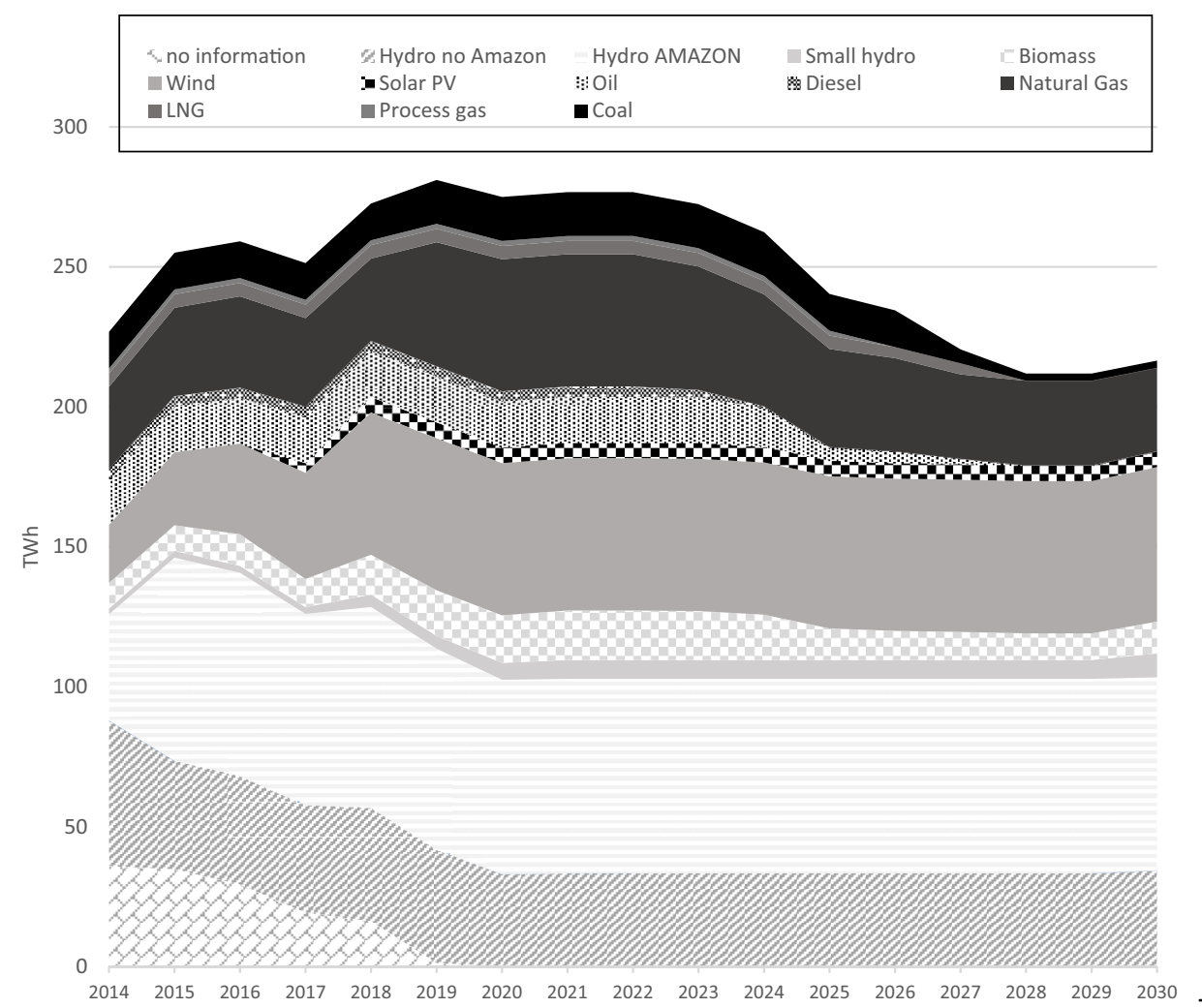

\section{Solar energy policy}

355
Figure 1.

Energy contracted in all auctions by year and by supply source (only valid contracts are considered) 


\begin{tabular}{|c|c|c|c|c|c|c|c|}
\hline \multirow[b]{2}{*}{$\begin{array}{l}\text { IJCCSM } \\
12,3\end{array}$} & \\
\hline & Type & & LER/2014 & $\begin{array}{l}1^{\circ} \mathrm{LER} / \\
2015\end{array}$ & $\begin{array}{l}2^{\circ} \mathrm{LER} / \\
2015\end{array}$ & $\begin{array}{l}25^{\circ} \mathrm{LEN} / \\
2017\end{array}$ & $\begin{array}{l}27^{\circ} \mathrm{LEN} / \\
2018\end{array}$ \\
\hline \multirow{4}{*}{356} & Qualified proposals & $\begin{array}{l}\text { Number of plants } \\
\text { Installed capacity (MW) }\end{array}$ & $\begin{array}{r}331 \\
8,871\end{array}$ & $\begin{array}{r}341 \\
11.261\end{array}$ & $\begin{array}{r}493 \\
13159\end{array}$ & $\begin{array}{r}315 \\
14.030\end{array}$ & $\begin{array}{r}422 \\
13380\end{array}$ \\
\hline & Winners & Number of plants & 31 & 30 & 33 & 20 & 29 \\
\hline & & Installed capacity (MW) & 889.6 & 833.6 & 929.3 & 790.60 & 807 \\
\hline & & Electricity Production in & 32.4 & 40.6 & 43 & 29.84 & 40.06 \\
\hline \multirow{4}{*}{$\begin{array}{l}\text { Table } 3 \text {. } \\
\text { Selected results } \\
\text { regarding solar } \\
\text { auctions in the period } \\
2014-2018\end{array}$} & & $\begin{array}{l}\text { Price of energy (US } \\
\$ / \mathrm{MWh} \text { ) }\end{array}$ & $82-90$ & $84-87$ & $77-80$ & $43-44$ & 35 \\
\hline & & $\begin{array}{l}\text { Investment (billions of } \\
\text { US\$) }\end{array}$ & 1.67 & 1.61 & 1.65 & 1.17 & 1.27 \\
\hline & & $\begin{array}{l}\text { Reduction in price, } \\
\text { compared to forecast } \\
\text { market price (deságio) }\end{array}$ & 17.9 & 13.9 & 21.9 & 56 & 62.2 \\
\hline & \multicolumn{7}{|c|}{$\begin{array}{l}\text { Note: LER, Reserve energy auction; LEN, New energy auction } \\
\text { Source: Adapted from CCEE (2018a) and EPE (2014 2015, 2016c) }\end{array}$} \\
\hline
\end{tabular}

energy reserve. In the most recent auctions, the distributors bought the solar energy as electricity from other sources. In Table 3, it is still important to highlight the relative stability in the number of qualified proposals: between 315 and 493. It is worth noting that the price of energy in dollars per megawatt-hour reduced sharply, from US\$82-90/MWh in 2014 to US\$35/MWh in 2018. The reduction in the initial price increased from $17.9 \%$ to $62.2 \%$ between the first and the fifth auctions; this represents the linkage - from the one side, the expectation by the government of the cost of the technology, and from the other side, the expectation by the market of profits and risks.

2.2.2 Net metering regulation in Brazil. In April 2012, the regulatory agency, Agência Nacional de Energia Elétrica (ANEEL) published the normative resolution RN 482/2012 introducing a system of net metering in the Brazilian power system, as a mechanism for incentivizing distributed generation (ANEEL, 2012). This system uses a bidirectional counter installed by the distribution companies, allowing consumers who produce power to inject their surplus energy into the grid and balance it with consumption at times of lower production. Energy bills, however, never reach zero because of a minimum payment awarded to the distribution companies for the costs of electricity availability. This minimum established by RN 414/2010 is very important in defining the size of installed rooftop systems (Vilaça Gomes et al., 2018).

One challenge faced by this mechanism was the effect of value-added tax (VAT or ICMS as the Portuguese acronym, for tax on the circulation of products and services) on the electricity provided to the grid through rooftop systems. This bottleneck effect is cited by both Vilaça Gomes et al. (2018) and Ferreira et al. (2018). The solution to this problem involves ANEEL, the 27 states of the country receiving the VAT and the National Financial Policy Council (CONFAZ). In 2015, these boards published Agreement 16 allowing the states to apply VAT to the balance of energy; 23 of the 27 states adhere to this Agreement (CONFAZ, 2015).

ANEEL's RN 687/2015 supported incentives for a distributed system using net metering, extending the compensation deadline to 60 months, increasing the limits of installed capacity and the creation of three new figures (ANEEL, 2015). One figure is remote consumption when production and consumption can occur at different sites (produced by 
the same owner/supplier) within the region of the same distribution company. The other two possibilities are multiple consumption units and shared generation: the first case involves one producer and several consumers and the second has multiple generators that can compensate each other in terms of production and consumption before to trading with the grid (Sugawara and Nikaido, 2014).

The number of PV facilities grew rapidly in 2017, despite national economic crises, and the number of installed units increased by $168 \%$ and $141 \%$ in 2018. Figure 2 brings a comparison between the GDP evolution and the PV distributed installations, the figure shows that the increase in solar distributed generation is high despite the crisis. On 3 June 2019, there were 78,936 PV distributed generators registered on the ANEEL database, considering all sectors and all generation modes (site consumption, remote consumption, shared generation and multiple consumption). There were 58,510 residential PV panels connected to the grid, with the majority $(51,138)$ located at the consumption site. There were some remote PV units for self-consumption (7,197), shared generation (149) and multiple consumption (26) (ANEEL, 2019a).

Future projections by ANEEL (2017) point to the continuity of this exponential growth, predicting that 886,700 micro generators will be connected to the network in $2024,91 \%$ of which will be residential and the remaining $9 \%$ in commercial buildings (ANEEL, 2017). In 2018 , the commercial sector represented $17 \%$ of generators and accounted for $43 \%$ of PV contributions from distributed generation (ANEEL, 2019a).

\section{Future solar incentive mechanism assessment through the TIMES model}

This section presents a case study of a suggestion of a policy design with the most costefficient values for solar deployment, accompanied by a batch of incentive mechanisms for solar energy for Brazil. The first subsection describes the Brazilian power sector and the second subsection explains the methodology used, proposing the optimum values for solar energy in different forms (PV utility-scale, PV distributed and concentrated solar power
Solar energy policy

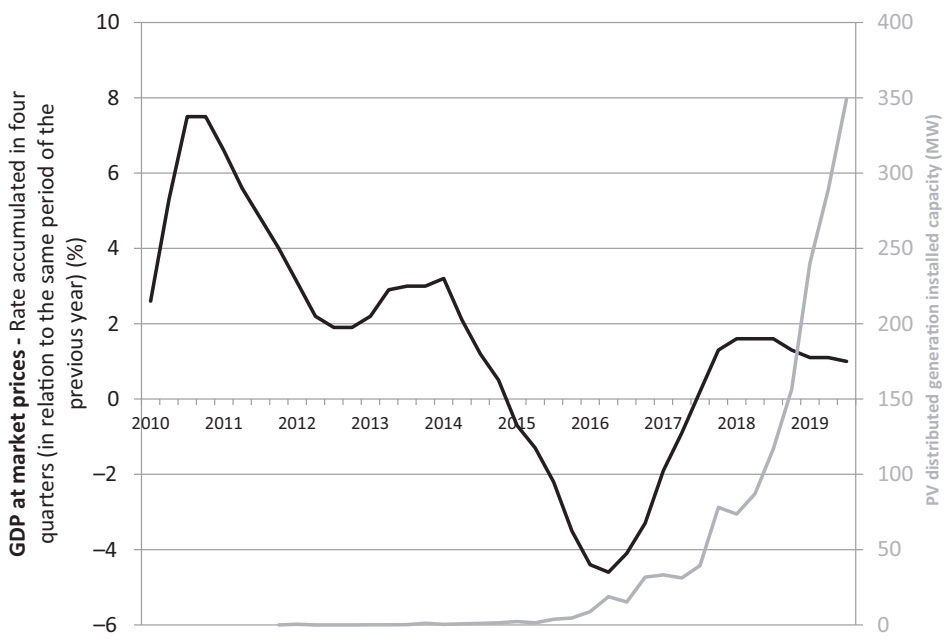

Source: ANEEL (2019b), IBGE (2020)
Figure 2. Comparison between the GDP and PV distributed generation 
IJCCSM 12,3

[CSP]) and describing incentive mechanisms. The third subsection presents three suggestions of incentives, one for each solar deployment form.

\subsection{Context: the Brazilian power system}

The Brazilian power system includes approximately 82 million users consuming 467 TWh in 2017 (EPE, 2018) and a national per capita consumption average of 2,525 kWh per capita. In 2018, the total installed capacity of the 7,440 Brazilian electrical generators was $164.8 \mathrm{GW}$ (ANEEL, 2019a). The electricity supply is predominantly based on hydropower, generating $63.1 \%$ of national electricity in 2017, while thermoelectricity represents around $27 \%$, including natural gas, oil, coal and nuclear, as well as renewables such as biomass from agricultural processes, mainly sugar cane products and forest products such as black liquor and charcoal. Wind power increased more than 123 -fold, from $342 \mathrm{GWh}$ in 2006 to 42,373 GWh in 2017 (EPE, 2011, 2018), representing 7.2\% of the total electricity generated in the country.

The Brazilian power system has a centralized planning framework, with a national operator of the system (ONS) and ANEEL, the national regulator of the system. The Brazilian electricity market faces some challenges, besides increasing power demands, hydrological risk and judicial action; namely, those related to technology improvements and environmental constraints (MME, 2018). The latter refers to potential environmental impacts associated with the big Amazon dams, rendering planned expansions unfeasible (EPE, 2007, 2017a). Technological challenges are related to the increased competitiveness of modern renewables, which are capital-intensive, have marginal costs (nearly zero) and are non-dispatchable energy sources.

Between July and August 2017, a new regulatory framework of the Brazilian electricity system was discussed (EPE, 2017b; MME, 2018). In the Brazilian context with high hydropower dependency, this could also mean the ability of a power source to alleviate the pressure on river flows, especially those in the basins which would be most impacted by climate change in the future, such as the São Francisco basin (de Queiroz et al., 2019).

\subsection{Methodology}

This paper aims to contribute to the energy policy in Brazil to deploy solar energy by exploring its potential, taking into account the characteristics of the country's power system, the existing resources and the expectations for the evolution of solar technologies. A twostep process was used: the first step suggests a national target for solar PV, taking a future PV technology pathway up to 2040 and the second step assesses how selected incentive mechanisms could be used to support such deployment.

The regulatory conditions to allow a multiplicity of business models to the deployment of solar energy is argued as a way to overpass barriers and consequently boost the deployment of renewable sources (Horváth and Szabó, 2018).

3.2.1 Energy system model to suggest solar targets. Energy modelling is widely used to explore how different policies may affect energy systems, namely, in terms of the expansion of renewables, emissions reductions and costs; modelling, therefore, has hEigh importance for energy planning. In this paper, energy system modelling will be used to identify future solar targets for Brazil, derived from cost-effective criteria and taking into account the characteristics of the energy systems. The expected development of the technical-economic characteristics of the energy technologies is also considered, namely, through cost-curves.

A TIMES model was used, which is a dynamic linear optimization bottom-up model generator, developed by the Energy Technology Systems Analysis Program (ETSAP) of the International Energy Agency (IEA). The ultimate objective of the TIMES model is the 
meeting of energy service demands at minimum cost across the total system (i.e. net surplus maximization), subject to technological, physical and policy constraints. The model computes the energy demand/supply equilibrium by making simultaneous decisions regarding equipment investment, primary energy supply and energy trade.

Energy-economic-environmental models have been used widely for the development of energy and climate policies (Fortes et al., 2014). Governments have adopted tools of this type in relation to the security of energy supply, mitigation of climate change and/or exchange costs (Østergaard, 2015). In general, these models have been used to help policymakers with decisions strongly linked to climate change (Simoes et al., 2015).

The cost-effective potential of the Brazilian solar energy system was assessed through a new TIMES-MARKAL based model named TIMES_BR_light, developed and calibrated for the Brazilian case. TIMES_BR_light refers to one region - the whole country and takes 192 timeslices (24 h of a typical day of each season, accounting for a weekday and a weekend day). The energy system consists of the primary sector, with mining and international trade, the transformation process (eight types) and final consumption by sector, with 202 processes. The final energy demand for the residential sector and other economic sectors (industry, commerce, public sector, transport and agriculture) are estimated exogenously to the model.

This modelling exercise provides an optimal technological deployment solution with the minimization of total system costs in line with the research time horizon. The most costeffective solution to the power supply is provided to accomplish the projected energy demand. The results of the amount of electricity generated by source (PV centralized, PV distributed and CSP) in this optimal solution are the basis of the solar targets assessed in this paper.

The assessment considers a scenario of a limitation in emissions in the power sector, equivalent to the reduction in total emissions in the NDCs in the Paris Agreement, i.e. a reduction of $43 \%$ in 2030 compared with 2005 . It is worth noting that this reduction is more ambitious than the projected reduction reported in the official NDCs for the power sector (emissions in 2030 of 20 Mton $\mathrm{CO}_{2 \mathrm{e}}$ instead of $73 \mathrm{Mton}^{\mathrm{CO}_{2 \mathrm{eq}}}$ ) (EPE, 2016a). The goal of this paper is to explore the cost-effectiveness of solar energy contributing to solving the current Brazilian "triple challenge." Solar is likely to be a bolder contributor to national emissions reductions, particularly in comparison with other power sources.

3.2.2 Incentives for solar deployment. A specific type of incentive mechanism is suggested for each technological solar target option (PV centralized, PV distributed and CSP) because of the following reasons. For centralized PV, it is argued that the best solution is the continuance of auctions on a regular basis, with a substantial increment of the capacity contracted in each auction. The previous auction results showed that private investment is available in the market and that competitiveness caused a significant reduction in the cost of electricity.

Solar thermal power on a large scale is still a costly technology, and therefore a competitive mechanism is suggested, where tenders are used to select the best offers in terms of investment price, technical quality and location. The winners agree on contracts directly with consumers in a free market environment and the government pays the difference between the higher technological costs and the alternative costs, for example, gas. This approach is similar to FIT but with a competitive approach. The rationality behind this mechanism is the increase of technological diversity in electricity deployment using the huge endogenous potential in an innovative, efficient, storable and dispatchable renewable source. 
IJCCSM

12,3

360

Figure 3.

Electricity generated in TIMES_BR_light model with a cap of emissions ab 2030
For distributed PV electricity generation, the enlargement of an existing green loan programme run by an official financial institution is suggested, given that grid, parity has already been achieved and that the technology requires a degree of support on a temporary basis to cope with the upfront costs. This solution could provide small investors who can help to increase the security system, without GHG emissions and at the national industrial scale the national industry.

These incentive mechanisms are analyzed in terms of cost, ability to adhere to stakeholder requirements and regulatory feasibility within the context of Brazilian energy policy.

\subsection{Suggested incentive mechanisms for solar energy in Brazil}

Mah et al. (2018) highlighted the fact that the establishment of a solar target is important for giving investors clear signals, for policy coordination and for setting the terms of new business models. The purpose of this paper is to use the results of electricity generated by source in the TIMES_BR_light model up to 2040, to show the viability and advantages of a solar vector. One way to take this path could be to have a solar target for Brazilian power and incentive mechanisms for it. The solar targets sector in the years 2030 and 2040 could be derived from the cost-effectiveness of solar technologies in comparison with other power technologies and the greenhouse emissions reduction for the power sector, following the expectations of the Paris Agreement. Therefore, this section presents how far Brazil could reach electricity production from solar resources, and the potential policies to achieve that potential.

3.3.1 Definition of the most cost-effective levels of deployment of solar energy. This section presents the most cost-efficient levels for solar energy deployment, taking the $\mathrm{CO}_{2}$ emissions cap as explained previously. Utility-scale solar PV generation will likely be $273 \mathrm{PJ}$

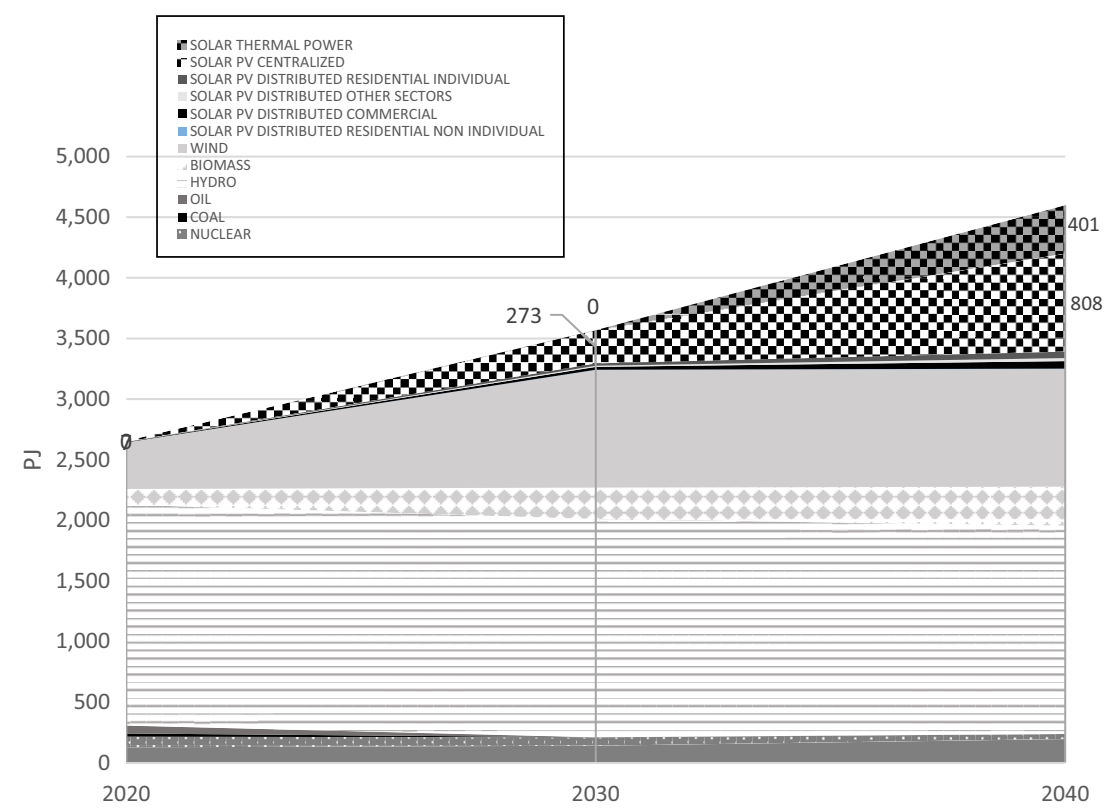


in 2030 and $808 \mathrm{PJ}$ in 2040 from an optimization perspective, accounting for $18 \%$ of the total electricity production in 2040, which demonstrates the competitiveness of solar energy.

Figure 3 shows the total electricity generated by energy source; the majority of fossil fuels are phased out, except natural gas, which has a modest increase. Wind power increases until 2030 then stabilizes because of the maximum potential reached. Bioelectricity increases and solar power too. This last source presents the strongest growth.

The results of the model indicate that the cost-effective solar options are 92T Wh in 2030 (76 TWh PV-US and 15 TWh of PV-distributed) and 324 TWh in 2040 (224 TWh of PV-US, 111TWh of CSP and 40 TWh of PV-distributed). The solar technology that appears with the strongest and earliest is utility-scale PV, due to the lower investment cost and greater potential. With the expected increase in the demand for electricity, CSP technology would be used in 2040. The distributed options are not as expensive as CSP, but have a limited potential considered after the literature review for the construction model; for this reason, the participation of this technology is limited, even with a greater electricity demand in 2040.

3.3.2 Policy incentive mechanism assessment: auctions for utility-scale photovoltaic. Considering the optimization model results, to achieve a cap of $43 \%$ emissions reduction in the Brazilian power sector (compared with emissions in 2005), solar utility-scale PV may contribute significantly, as shown in Figure 2. However, to reach the most cost-efficient deployment of the technology, an incentive mechanism is suggested, the acceleration auction.

Considering the rate of auctions similar to 2018 (i.e. 3,500 GWh of additional electricity per annum, assuming that operation begins four years after the bid is won), 36.7 TWh of electricity in 2030 and 66.5 TWh in 2040 might be expected. These values are insufficient to meet the cost-effective potential, which means there is room for a more ambitious scheme.

The generation proposed here is an acceleration in auctions. In 2030, there should be at least $38,771 \mathrm{GWh}$ more than the amount currently contracted, with a sustained rate of new auctions continuing to generate $3,500 \mathrm{GWh} /$ year. This means that an additional 4,846 $\mathrm{GWh}$ per year in auctions in the period 2019-2026 and an additional 10,505 GWh per year between 2027 and 2036 would be required. These values would be substantially higher than the contracted $2003 \mathrm{GWh}$ cited in the 27th LEN ( Table 3). However, the total amount of viable projects presented in the 25th and 27th LEN would be 80,103 GWh, so the current market potential could be said to be under-exploited (EPE, 2017c).

Giving clear signs to the market, the acceleration could be carried out in two phases, the first one between 2019 and 2026, with a yearly addition of 5,585.57 GWh of new contracts above the continuity of the actions in the same rhythm as the 2018 auction.

In a second phase, the acceleration would be greater, and the new yearly contracts would need to be $11,320.70 \mathrm{GWh}$ above the rhythm of the 2018 auctions in the period between 2027 and 2036. The contracts considered here would made four years before the begging of the technological operation; then with this scheme, in 2040 the more cost-effective potential of the technology would be deployed.

3.3.3 Policy incentive mechanism assessment: competitive tenders for concentrated solar power. Examples of feasible free-market tender options might follow the French model, with three clear contract deadlines: 2025, 2030 and 2035. The use of direct power purchase agreements for thermal solar power between consumers and generators would be considered. Competitive tender processes should be used to select the best technical economical projects. Such projects should be eligible for financial support from the government or from the system as a whole by a sectoral funds review, for example, to compensate for higher technological costs. Regarding these results, a scenario of 186 plants of $100 \mathrm{MW}$ each could be considered. 
IJCCSM

12,3

Eligibility for participation in the competitive tender scheme would depend on the existence of a supply contract between the generator and the consumer or distribution company. The advantage for the generator of participating in this tender would be complementary revenue, in addition to electricity payments. Mechanism costs would be estimated in line with a $55 \%$ reduction in CSP electricity costs, equivalent to the forecasted reduction of investment costs between 2016 and 2040. Assuming electricity costs from CSP of US\$90.00/MWh or R $\$ 335.00 / \mathrm{MWh}$ and electricity costs from natural gas of R $\$ 213.00$, as seen in the latest auction (27th LEN), this would result in a difference of $\mathrm{R} \$ 122.00 / \mathrm{MWh}$ or $35 \%$ in relation with the cost of CSP.

In the initial phase, with a deadline application in 2025 , this represents $\mathrm{R} \$ 939 \mathrm{~m}$ per year, an amount similar to the national coal subsidy paid in 2018 for electricity produced using national coal ( $\mathrm{R} \$ 771 \mathrm{~m}$ in 2018) (CCEE, 2018b).

The logical model of the three phases for the adoption of this incentive mechanism suggested here is that the early adopters would have the greater advantage, but low participation would be expected; in the next phase, the advantages would be lesser but higher deployment would be expected. The generators would receive the value of the power contract in the free market, plus the difference between the cost of energy produced in the $\mathrm{CSP}$ plant and the cost of energy in the most recent natural gas auction. The three phases are different in terms of incentive to new CSP generators: in the first phase, the incentive would decrease and the CSP generator would receive the total difference plus $10 \%$ of the difference or $110 \%$ of the difference. In the second phase, there would be just the difference, and in the third phase, there would be $90 \%$ of the difference. A second difference of the three phases would be the ambition of the mechanism in each one: the first phase would see a small participation of CSP generators; the second one, on the other hand, would assume a high potential of investments; and the third phase would be almost all residual investments.

Compared to the French model, this proposed new mechanism presents some differences, namely, only solar thermal power projects would be allowed, without size or sectoral differentiation. The criteria to calculate the subsidy might follow different options. In the French case, this calculation considers the number of hours when the spot price is positive or zero, multiplied by the applicant's electricity price (in €/MWh), minus the benchmarked electricity price of all solar electricity producers. There is still a specific point of participative investments with a bonus of $3 € / M W h$.

The proposed design of a new incentive mechanism such as competitive tenders allows public policy not just to define which technology would receive the incentive and the associated timelines but also to decide where the load would be installed. It is argued that the northeast Brazilian submarket would be the most appropriate region for the development of this incentive mechanism because it has the highest irradiation and because there are some congestion costs. Besides that, this is one of the poorest parts of the country, one of the most populated semiarid regions in the world, and the economic basis of agriculture and cattle-raising tends to suffer greatly from climate change (Orsato et al., 2017).

3.3.4 Policy incentive mechanism assessment: green loans for distributing photovoltaic. An official bank in Brazil called Banco do Nordeste launched a loan programme in 2016 with a reduced interest rate and long payback period (12 years), named Fundo Constitucional de Financiamento do Nordeste (FNE Solar). Between May 2016 and October 2018, it funded 770 projects at a total of $\mathrm{R} \$ 124 \mathrm{~m}$, for non-household customers (Banco do Nordeste, 2018). The same programme is now open for residential customers.

The potential for solar distributed generation derived from the optimization energy model for Brazil is estimated as 16,667 GWh in 2030 and 44,722 GWh in 2040. Finding the 
means of realizing this potential could be a way to alleviate poverty in the northeast region of Brazil. This idea is aligned with the arguments provided by Nobre et al. (2019) that it is possible to change the paradigm and use in a better way the most abundant resource of the region: the sun.

As information about the technical characteristics of the projects was not found, to estimate the total of PV-distributed installed capacity and electricity generated, the price of distributed installations in the commercial sector was used, of R $\$ 4.31 / \mathrm{Wp}$ in June 2018 (GREENER, 2018). With total cost and cost per watt, the estimated installation supported by the FNE-Sol program is $28.87 \mathrm{MW}$ of installed capacity currently in operation. Using a $20 \%$ availability factor, $51 \mathrm{GWh}$ of annual electricity production was found at distribution level in the 770 existing projects, which means on average a cost of $\mathrm{R} \$ 2.44 \mathrm{~m} / \mathrm{GWh}$ in the 770 existing projects.

To accomplish the cost-effective potential in 2030, the additional electricity generated annually should be $1,385 \mathrm{GWh}$, requiring $\mathrm{R} \$ 3.4 \mathrm{bn}$ available for a loan each year until 2030 . For 2040, a total of $\mathrm{R} \$ 6.85 \mathrm{bn}$ of financial support would be required.

Considering that it is a loan, the cost of the mechanism must be calculated based on the difference in the interest rate. This loan has a lower interest rate (1.67\% yearly of fixed-rate) than the average interest rate in the country (6.5\% yearly). If solely this difference is considered between both the aforementioned interest rates and transaction costs are not considered, then the cost of the mechanism in 2016 was about $\mathrm{R} \$ 1.9 \mathrm{~m}$ and in 2040 the annual cost would be $\mathrm{R} \$ 3.8 \mathrm{bn}$. The loans are provided by a public regional development bank with public resources for private companies.

Banco do Nordeste affirmed that the demand rate for loans in the FNE Sol program was below the available resource for the scheme and should the demand for such loans increase, the bank could redirect resources, from other programmes into this one (Banco do Nordeste, 2019). In the future, with market growth, other financial options for distributed generation investment might be designed.

\section{Conclusions}

The objective of the paper is to propose a solar energy policy and thus the definition of solar targets and incentive mechanisms to achieve this. This paper proposes six solar targets for electricity generated in 2030 and 2040, from PV at utility-scale and at a distributed level and CSP or solar thermal power. This step is the first contribution of this work, serving as an initial point of discussion and signifying that the market needs to grow and the government needs to define specific policy targets. The suggestions of this study are the results of the optimization model, representing the most cost-efficient solution. This considers the previously explained assumptions and an additional condition, the potential for the Brazilian power sector to reduce its emissions to a level below the official forecast, as solar energy is part of this picture, and this ambition is reflected in the solar targets.

Reaching these goals, although cost-efficient, involves a paradigm shift from a hydrothermal-based electricity sector to an electricity sector with more solar and wind power. This process is not straightforward: it will affect the public and private investment decisions of millions of different economic agents, groups whose behaviour is determined by both economic and non-economic reasoning.

When the social benefits outweigh the public costs, public policies are required to play a crucial role in energy transition. This work suggests a batch of incentive mechanisms for solar energy deployment, such as public policies to meet future electricity demand in a more efficient and sustainable way. 
IJCCSM 12,3

The batch is not exclusive as the mechanisms are independent; however, deploying them jointly or deploying other similar mechanisms would lead to solar targets being reached. It is likely that during the development of the solar energy market to the stage suggested within this paper, additional complementary or concurrent business models would emerge. This movement would bring about the need for reviewing mechanisms naturally.

The first and second mechanisms, "acceleration of auctions" and "competitive tenders" seem to have similar focus groups, but as explained in the Sections 3.3.2 and 3.3.3, there are two different market environments in the Brazilian electricity market; each mechanism addresses one of these environments. Nowadays, the majority of the market is regulated, but the free market environment is increasingly under discussion. The suggested mechanism assumes that at present, only the regulated environment would be affected, but in the future, the mechanism designed for the free market would also have a place.

In the distributed sector, this mechanism involves investment decisions of many more economic agents, and the rate of implementation is smoother. To represent this feature of distributed energy, the deployment potential of these technologies is not constant but grows within the timelines of the TIMES_BR_light model.

The continuity and strengthening of existing incentive mechanisms, such as periodical solar auctions and distributed generation investment loans, combined with new mechanisms such as competitive tenders and applied to technologies which are still too costly for the market, may be an efficient way to incentivize the deployment of solar energy on a large scale. This process would help the country face the challenges of growing demand and the limitations on hydroelectric potential, without increasing greenhouse gas emissions. This, however, depends on public policies having a strong receptiveness for new, large-scale renewable sources. Business-as-usual practices and current policies are not sufficient to reach the potential of solar energy in Brazil or the Paris Agreement goals.

The main limitations of this work are that:

- the model assumed a low spatial granularity; the country is considered as just one region; and

- despite new solar auctions being considered a successful policy, specific details of possible adaptations to better suit the features of the solar source are not included in this study.

\section{Note}

1. In the Brazilian electricity market, there are two environments for contracting, the regulated and the free. The first one is related to captive consumers where the distributor is a mandatory agent; the latter does not have this characteristic, but has limitation access, where only the big consumers are eligible.

\section{References}

ANEEL (2012), "Resolução normativa no 482 de 17 de abril”, Aneel, available at: www2.aneel.gov.br/ cedoc/ren2012482.pdf

ANEEL (2015), "Resolução normativa no 687 de 2015 Da ANEEL”, Aneel, available at: www2.aneel. gov.br/cedoc/ren2015687.pdf

ANEEL (2017), "Nota tecnica 056/2017", available at: www.aneel.gov.br/documents/656827/15234696/ Nota+Técnica_0056_PROJEÇÕES+GD+2017/38cad9ae-71f6-8788-0429-d097409a0ba9 
ANEEL (2019a), "Unidades consumidoras com geração Distribuída - Fevereiro 2019”, available at: www2.aneel.gov.br/scg/gd/GD_Classe.asp

ANEEL (2019b), “1_Base SISGD - LAI 6881-2019. Personal comunication”.

Aquila, G., Pamplona, E.D.O., Queiroz, A.R. D., Rotela Junior, P. and Fonseca, M.N. (2017), "An overview of incentive policies for the expansion of renewable energy generation in electricity power systems and the Brazilian experience", Renewable and Sustainable Energy Reviews, Vol. 70, pp. 1090-1098.

Banco do Nordeste (2018), "Resultado impactos FNE exercício de 2017”, available at: www.sudene.gov. br/images/2018/arquivos/7_-_FNE-RelatórioResultadosImpactos2017.pdf

Banco do Nordeste (2019), "Resposta de pedido de Informação - Lei 12.527 - personal comunication email NUP. 99905000213201842 ".

CCEE (2018a), "Resultado_consolidado_publicacao_abril18”, available at: www.ccee.org.br/ccee/ documentos/CCEE_640324

CCEE (2018b), "relatório orçamento das contas setoriais 2018 - cde/rgr/ccc", available at: www.ccee. org.br/ccee/documentos/CCEE_505032

CONFAZ (2015), “Convênio ICMS 16, de 22 de abril de 2015”, available at: www.confaz.fazenda.gov.br/ legislacao/convenios/2015/CV016_15

de Queiroz, A.R., Faria, V.A.D., Lima, L.M.M. and Lima, J.W.M. (2019), "Hydropower revenues under the threat of climate change in Brazil", Renewable Energy, Vol. 133, pp. 873-882.

Dutra, J. and Menezes, F. (2005), "Lessons from the electricity auctions in Brazil", The Electricity Journal, Vol. 18 No. 10, pp. 11-21.

EPE (2007), "Plano nacional de energia 2030", EPE, available at: http://epe.gov.br/pt/publicacoes-dadosabertos/publicacoes/Plano-Nacional-de-Energia-PNE-2030

EPE (2011), "Anuário estatístico de energia elétrica 2011", available at: http://epe.gov.br/pt/publicacoesdados-abertos/publicacoes/anuario-estatistico-de-energia-eletrica

EPE (2014), "Leilão de energia de reserva de 2014. Participação dos empreendimentos solares fotovoltaicos: Visão geral", Brasil, Empresa de Pesquisa em Energia, available at: www.epe.gov.br/sites-pt/ publicacoes-dados-abertos/publicacoes/PublicacoesArquivos/publicacao-94/NT_EPE-DEENT-150_2014.pdf

EPE (2015), "Expansão Da geração. $1^{\circ}$ leilão de energia de reserva de 2015. Participação dos empreendimentos solares fotovoltaicos: Visão geral no. EPE-DEE127/2015-R0", Brasil, Empresa de Pesquisa em Energia, available at: http://www.epe.gov.br/sites-pt/publicacoes-dados-abertos/ publicacoes/PublicacoesArquivos/publicacao-73/NT_EPE-DEE-NT-127_2015-r0_completo.pdf

EPE (2016a), "O compromisso do brasil no combate Às mudanças climáticas: produção e uso de energia", available at: http://epe.gov.br/sites-pt/publicacoes-dados-abertos/publicacoes/PublicacoesArquivos/ publicacao-308/NTCOP21iNDC.pdf\#search=ocompromissobrasileiro

EPE (2016b), "Energia renovável: Hidráulica, biomassa, eólica, solar, oceânica”, EPE, available at: www.epe.gov.br/sites-pt/publicacoes-dados-abertos/publicacoes/PublicacoesArquivos/ publicacao-172/EnergiaRenovável-Online16maio2016.pdf

EPE (2016c), "Expansão da geração. $2^{\circ}$ leilão de energia de reserva de 2015. Participação dos empreendimentos solares fotovoltaicos: Visão geral N o. $\{\mathrm{EPE}\}-\{\mathrm{DEE}\}-\{\mathrm{NT}\}-023 / 2016-\mathrm{r} 0 "$ ", Brasil, Empresa de Pesquisa em Energia.

EPE (2017a), "Plano decenal de expansão da energia 2026", available at: www.epe.gov.br/sites-pt/ publicacoes-dados-abertos/publicacoes/PublicacoesArquivos/publicacao-40/PDE2026.pdf

EPE (2017b), "Processamento de contribuições à consulta pública no 33/2017 e recomendações de alterações Para a elaboração de instrumento Legal - Nota técnica EPE-PR-003/2017", available at: www.epe.gov.br/sites-pt/publicacoes-dados-abertos/publicacoes/PublicacoesArquivos/publicacao232/topico-353/NotaTécnicaEPE-PR-003-2017.pdf\#search=consulta33 


\section{IJCCSM}

12,3

EPE (2017c), "Informe técnico leilão A4 energia nova”, available at: www.epe.gov.br/sites-pt/publicacoesdados-abertos/publicacoes/PublicacoesArquivos/publicacao-268/InformeLeilões2017-Portugues. pdf

EPE (2018), “Anuário estatístico de energia elétrica 2018 - Ano base 2017”, available at: www.epe.gov. $\mathrm{br} / \mathrm{pt} /$ publicacoes-dados-abertos/publicacoes/anuario-estatistico-de-energia-eletrica

FEDERATIVE REPUBLIC OF BRAZIL (2015), "Intended nationally determined contribution towards achieving the objective of the paris agreement", available at: www4.unfccc.int/sites/ndcstaging/ PublishedDocuments/BrazilFirst/BRAZILiNDCenglishFINAL.pdf

Ferreira, A., Kunh, S.S., Fagnani, K.C., De Souza, T.A., Tonezer, C., Dos Santos, G.R. and CoimbraAraújo, C.H. (2018), "Economic overview of the use and production of photovoltaic solar energy in brazil”, Renewable and Sustainable Energy Reviews, Vol. 81, pp. 181-191.

Fortes, P., Pereira, R., Pereira, A. and Seixas, J. (2014), "Integrated technological-economic modeling platform for energy and climate policy analysis”, Energy, Vol. 73, pp. 716-730.

GREENER (2018), "Strategic market study - solar photovoltaic Market - distributed generation (DG) 2nd semester 2018", available at: www.greener.com.br/en/strategic-study-dg-1stsemester-2018/

Horváth, D. and Szabó, R.Z. (2018), "Evolution of photovoltaic business models: overcoming the main barriers of distributed energy deployment", Renewable and Sustainable Energy Reviews, Vol. 90, pp. 623-635.

IBGE (2020), “Contas nacionais Trimestrais - SIDRA - Tabela 5932”, available at: https://sidra.ibge. gov.br/tabela/5932\#resultado

IEA (2017a), "World energy investment 2017”, available at: https://doi.org/10.1787/9789264277854-en

IEA (2017b), "Trends in PHOTOVOLTAIC APPLICATIONS", International Energy AgencyPhotovoltaic Power Systems, Vol. T1 No. 32.

IEA (2018), "World energy outlook 2018", available at: www.oecd-ilibrary.org/energy/world-energyoutlook-2018/executive-summary_weo-2018-2-en

IEA-PVPS (2018), Annual Report 2017, available at: www.iea-pvps.org/index.php?id=6

IRENA (2016), "Unlocking renewable energy investment: the role of risk mitigation", available at: www.irena.org/publications/2016/Jun/Unlocking-Renewable-Energy-Investment-The-role-of-riskmitigation-and-structured-finance

Kitson, L. Wooders, P. and Moerenhout, T. (2011), "Subsidies and external costs in electric power generation: a comparative review of estimates, sustainable development", available at: https:// www.iisd.org/gsi/sites/default/files/power_gen_subsidies.pdf

Mah, D.N., yin, Wang, G., Lo, K., Leung, M.K.H., Hills, P. and Lo, A. Y. (2018), "Barriers and policy enablers for solar photovoltaics (PV) in cities: perspectives of potential adopters in Hong Kong", Renewable and Sustainable Energy Reviews, Vol. 92 (September 2017), pp. 921-936, doi: 10.1016/j. rser.2018.04.041

MME (2018), "Proposta compilada de aprimoramento do marco legal do setor Elétrico - Consulta pública 33", available at: www.mme.gov.br/c/document_library/get_file?uuid=6a984cf2-f63b3ad1-cafc-0f98c4ef7a21\&groupId=36131

Nobre, P., Pereira, E.B., Lacerda, F.F., Bursztyn, M., Haddad, E.A. and Ley, D. (2019), “Solar smart grid as a path to economic inclusion and adaptation to climate change in the Brazilian semiarid Northeast", International Journal of Climate Change Strategies and Management, Vol. 11 No. 4, doi: 10.1108/IJCCSM-09-2018-0067.

Ofgem (2018), "Renewables obligation: closure of the scheme in England, Scotland and Wales", available at: www.ofgem.gov.uk/system/files/docs/2018/04/ro_closure_guidance_-mar2018_final_0.pdf

Orsato, R.J., Barakat, S.R. and de Campos, J.G.F. (2017), “Organizational adaptation to climate change: learning to anticipate energy disruptions", International Journal of Climate Change Strategies and Management, Vol. 9 No. 5, pp. 645-665. 
Østergaard, P.A. (2015), "Reviewing EnergyPLAN simulations and performance indicator applications in EnergyPLAN simulations", Applied Energy, Vol. 154, pp. 921-933.

REN21 (2017), "Renewables 2017 Global Status Report”, available at: www.ren21.net/wp-content/ uploads/2019/05/GSR2017_Full-Report_English.pdf

REN21 (2018), Renewables 2018 Global Status Report, available at: https://doi.org/978-3-9818911-3-3

Rialp-Criado, A., Barcelona, U.A. and Cerdanyola, B. (2019), "Home (not so) sweet home domestic political uncertainty driving early energy context", Critical Perspectives on International Business, doi: 10.1108/cpoib-03-2018-0031.

Simoes, S., Fortes, P., Seixas, J. and Huppes, G. (2015), "Assessing effects of exogenous assumptions in GHG emissions forecasts - a 2020 scenario study for Portugal using the times energy technology model", Technological Forecasting and Social Change, Vol. 94, pp. 221-235.

Sugawara, E. and Nikaido, H. (2014), "Properties of AdeABC and AdeIJK efflux systems of Acinetobacter baumannii compared with those of the AcrAB-TolC system of Escherichia coli”, Antimicrobial Agents and Chemotherapy, Vol. 58 No. 12, pp. 7250-7257.

UNFCCC (2019), "Greenhouse gas inventory data - detailed data by party", available at: https://di. unfccc.int/detailed_data_by_party

Vilaça Gomes, P., Knak Neto, N., Carvalho, L., Sumaili, J., Saraiva, J.T., Dias, B.H., Miranda, V. and Souza, S.M. (2018), "Technical-economic analysis for the integration of PV systems in Brazil considering policy and regulatory issues", Energy Policy, Vol. 115, pp. 199-206.

Ye, L.C., Rodrigues, J.F.D. and Lin, H.X. (2017), "Analysis of feed-in tariff policies for solar photovoltaic in China 2011-2016”, Applied Energy, Vol. 203, pp. 496-505.

\section{About the authors}

Juliana Pacheco Barbosa is a Researcher at Instituto Universitário de Lisboa (ISCTE-IUL), DINÂMIACET. He is a $\mathrm{PhD}$ candidate in Climate Change and Policy for Sustainable Development at the Universidade Nova de Lisboa, Master's degree in with an equivalence recognized by the Master's degree in economics from ISCTE-IUL and a bachelor of economic science by Universidade Federal da Paraíba - UFPB (2001). She has worked as a lecturer at the UFPB, as a public policy specialist at the Brazilian Ministry of the Environment and as a consultant for national and international organizations. Her research interests are related to the transition and diversification of energy systems. Juliana Pacheco Barbosa is the corresponding author and can be contacted at: jpa.barbosa@ campus.fct.unl.pt

Joisa Dutra Saraiva is a PhD in Economics from Fundação Getulio Vargas, in Rio de Janeiro (2001), she was director of the National Electric Energy Agency (ANEEL), between 2005 and 2009. Visiting professor at Harvard Kennedy School of Government, Harvard University, in 2010 and professor at Fundação Getulio Vargas, in Rio de Janeiro. She has experience in Economics, working mainly in the following areas: Regulatory Economics, Energy Economics, Auctions, Experimental Economics, Organizational Theory and Contracts. She has been director of the Infrastructure Regulation Center (FGV CERI) since 2010.

Julia Seixas is a Professor in the areas of Remote Sensing in Environment and Energy and Climate Change. Coordinates the Energy and Climate group at CENSE research center, dedicated to R\&D towards carbon neutrality: energy systems integrated modelling, new energy technologies, new policy instruments, sustainable cities, climate vulnerability and adaptation of energy systems. More than 60 publications in international scientific journals. Coordinates studies to support the national public policy on climate mitigation for more than 20 years. Coordinates the Climate-KIC Hub Portugal since 2016. President of the Department of Environmental Sciences and Engineering since March 2017.

For instructions on how to order reprints of this article, please visit our website:

www.emeraldgrouppublishing.com/licensing/reprints.htm

Or contact us for further details: permissions@emeraldinsight.com 